\title{
The Covid-19 Pandemic and the Moroccan Financial Market: An Event Study
}

\section{Mouncif HARABIDA ${ }^{1}$}

Bouchra RADI

I, Ibn Zohr University, ENCG,
Morocco.
Email: mouncif.harabida@edu.uiz.ac.ma
'Email: radi.bouchra@gmail.com
Licensed:
This work is licensed under a Creative
Commons Attribution 4.o License.
Keywords:
Coronavirus
Event study
Stock market
Abnormal return
Morocco.
Received: 12 August 2020
Revised: 31 August 2020
Accepted: 7 September 2020
Published: 15 September 2020
(* Corresponding Author)

\begin{abstract}
The history of global health crises has been aggravated by the spread of the new coronavirus pandemic (Covid-19), which caused disruptions in the economic and financial systems of the various countries, particularly the financial markets. This paper examines the impact of the spread of the pandemic, in the Moroccan context, on its financial market from February 24, 2020 to May 5, 2020. We use the day of the outbreak of the state of health emergency in Morocco, March 16, 2020, as the day of the event. In order to evaluate the reaction of the prices of companies listed on the Casablanca Stock Exchange, we use the event study methodology which is based mainly on the calculation of the daily abnormal returns of each company, and cumulate them over an event window in order to test their statistical significance. Our conclusions confirm the negative influence of the Covid-19 pandemic on the Moroccan financial market. We find that the market reactions are more important on short event windows, especially on the days surrounding the date of the event, while the reaction is less important on long event windows.
\end{abstract}

Funding: This study received no specific financial support.

Competing Interests: The authors declare that they have no competing interests.

\section{Introduction}

From its first appearance in the Chinese city of Wuhan, Covid-19, which includes both Severe Acute Respiratory Syndrome (SARS) and Middle Ear Syndrome (MOS) viruses, has caused havoc around the world because of its highly communicable nature.

Following its exponential spread in different continents, the World Health Organization (WHO) characterized it, on March 11, 2020, as a pandemic disease. From then on, rigorous preventive measures were taken in the different countries, including total or partial containment, cancellation of inter-country travel, which caused a paralysis of economic activities and consequently countries have led to a sharp downward revision of their growth projections for 2020.

However, in a world marked by globalization and free trade between countries, the pandemic was able to destabilize Morocco by causing considerable health damage. In fact, cases of infection have exceeded 6600 cases with 190 deaths. However, Morocco is considered among the countries that have benefited from the experience of other countries in the spread of the pandemic by implementing fairly rigorous crisis management strategies, to the detriment of their economic growth. Moreover, the International Monetary Fund (IMF) has predicted, in its April 2020 report 1, a drop in the growth of the Moroccan economy of 3.7\% during the current year.

On the financial level, the Moroccan financial market recorded losses, in fact, according to the report of the Financial Market Authority (the AMMC), the stock market indices MASI and MADEX recorded respectively a fall of $20.85 \%$ and $21.26 \%$ during the month of March bringing their respective annual performances to $-20.27 \%$ and $-20.59 \%{ }^{2}$.

The purpose of this article is to study the impact of the health crisis caused by the coronavirus on the Moroccan financial market. To do so, we will first present the literature review, then the research

\footnotetext{
${ }^{1}$ World Economic Outlook, April 2020.

2 AMMC's Stock Market Investor Profile Report for April 2020.
} 
methodology, then we will present and discuss the results of the study and finally we will conclude and propose future research avenues.

\section{Literature Review and Hypothesis Development}

During the 1960s, the financial literature was enriched by the famous contribution of Fama, Fisher, Jensen, and Roll (1969) who introduced the term "Efficient Market". However, Fama (1970) introduced the semi-strong form of market efficiency, arguing that stock prices adapt quickly to new public information. In other words, prices will be driven by new information and are influenced in a very rapid manner. This kind of public information includes company announcements (Scholes, 1972) changes in economic policy, regime change, natural disasters and epidemics. As a result, market efficiency is considered to be a basic assumption of the methodology for studying events.

However, several non-economic events have been the subject of empirical studies aimed at studying their impact on financial markets. These include natural disasters (Worthington, 2008) air pollution (Lepori, 2016) air disasters (Kaplanski \& Levy, 2010), and acts of terrorism (Chesney, Reshetar, \& Karaman, 2011; Choudhry, 2005; Corbet, Gurdgiev, \& Meegan, 2018; Karolyi, 2006) weather (Hirshleifer \& Shumway, 2003) and infectious diseases (Almarayeh, 2020; Ashraf, 2020; Chen, Jang, \& Kim, 2007; Nippani \& Washer, 2004; Sansa, 2020; Şenol, 2020).

Numerous pandemics have marked the history of global health crises, including SARS in 2003, H1N1in 2006 and the Ebola Virus in 2014-2016. The financial literature has continued to keep pace with the spread of the latter, focusing on assessing their effects on economies in general and financial markets in particular. Among the most noteworthy contributions is that of Nippani and Washer (2004) who examined the impact of avian influenza (SARS) on the financial markets of China, Canada, Indonesia, the Philippines, Singapore, Thailand and Vietnam. He concluded that SARS has not had a negative impact on the financial markets with the exception of China and Vietnam.

Similarly, Chen et al. (2007) investigated the effect of the SARS pandemic on the stock price movements of Taiwanese hotels through an event study. Their results suggest that the stocks of these companies posted significantly negative average cumulative abnormal returns, indicating a significant impact of the SARS epidemic on hotel stock returns.

Scientific research has taken a new direction following the strong spread of the Covid-19 pandemic. Recently, Sansa (2020) studied the impact of the Covid-19 pandemic on global financial markets between 21 January 2020 and 7 April 2020. The global markets were represented by the Morgan Stanley Capital International (MSCI) World Index, as well as emerging market, European and G7 indices. Covid-19 was expressed by the number of deaths. The results of Senol's study show that Covid-19 had a negative impact on the markets.

For example, Ashraf (2020) examined the response of the stock markets of 64 countries, including Morocco, to the Covid-19 pandemic during the period from 22 January 2020 to 17 April 2020. The results reveal that financial markets reacted negatively to the growth of confirmed Covid-19 cases. The study therefore suggests that the negative market reaction was strong during the first days of confirmed cases and then between 40 and 60 days after the confirmed cases.

Indeed, Ali, Alam, and Rizvi (2020) measured the response of global financial markets to the spread of the virus during the epidemic and pandemic period (1 January 2020 to 20 March 2020). The study sample includes the nine countries most affected by the pandemic, including China, the United States of America, the United Kingdom, Italy, Spain, France, Germany, Switzerland and South Korea. The results indicate that the Chinese market showed a relatively smaller decline in returns in both the epidemic and pandemic phases, while other financial markets such as the United States, the United Kingdom, Germany and South Korea experienced an overall average volatility that increased significantly from the epidemic to the pandemic period.

In contrast, Wang and Enilov (2020) conducted a study on the overall effect of Covid-19 on the financial markets of the world's most industrialized countries (G7) between 17 February 2020 and 9 April 2020. This study tested the hypothesis that the number of new cases of coronavirus (COVID-19) significantly influences equity returns in international financial markets. The results suggest that the spread of COVID-19 has established a dominant short-term influence on the movements of equity returns in international financial markets.

Similarly, Liu, Manzoor, Wang, Zhang, and Manzoor (2020) assessed the short-term impact of the coronavirus epidemic on the stock market indices of the major affected countries, including Japan, Korea, Singapore, the United States, Germany, Italy and the United Kingdom, among others. By means of an event study, the results of the study proved that the COVID-19 epidemic has a negative effect on stock market returns in all countries, particularly Asian countries, which recorded more negative abnormal returns than other countries.

In a more limited context, Sansa (2020) examined the impact of Covid-19 on financial markets from 1 March 2020 to 25 March 2020 in China and the United States. Using a regression model, Sansa (2020) examined the impact of Covid-19 on the financial markets in China and the United States from 1 March 2020 to 25 March 2020. Sansa (2020) tested the correlation between Covid-19, represented by the number of 
confirmed cases, and the Chinese and US financial markets, represented by the Shanghai Composite and the Dow Jones, respectively. The results of the study revealed that there is a positive and significant correlation between Covid-19 and the two financial markets from March 1, 2020 to March 25, 2020.

In the Asian context, Al-Awadhi, Al-Saifi, Al-Awadhi, and Alhamadi (2020) assessed the effect of the covid-19 pandemic on the performance of Chinese companies listed in the Hang Seng Index and the Shanghai Stock Exchange Composite Index during the period from January 10 to March 16, 2020. The results of their study suggest that Covid-19, as represented by the total number of confirmed cases and the total number of deaths, has negative effects on the stock performance of all companies. Similarly, Bora and Basistha (2020) empirically studied the effect of Covid-19 on the Indian stock market between 3 September 2019 and 10 July 2020. They found that the stock market in India experienced some volatility during the pandemic period.

However, the financial markets in Arab countries have shown a reaction to the spread of the virus. For example, Almarayeh (2020) studied the reaction of stock markets to the global Covid-19 pandemic in developing countries. The study covers the period from 29 January 2020 to 1 June 2020 with a sample of 13 countries in the MENA region, namely: Turkey, Saudi Arabia, United Arab Emirates (UAE), Qatar, Bahrain, Oman, Jordan, Palestine, Iraq, Lebanon, Egypt, Morocco and Tunisia. The results show that the financial markets reacted negatively to the increase in the number of deaths, while the stock markets did not react to the daily growth in the number of cases confirmed by Covid-19.

Based on the literature on infectious diseases and financial markets, we conclude that pandemics often have negative influences on financial markets. As a result, we formulate the following research hypothesis:

H1: The Covid-19 pandemic has a significant impact on the Moroccan financial market.

\section{Research Method}

In this section, we will present the fundamentals of the methodology of the event study, then we will present the sample and the time series of the study, and finally we will present the regression model.

\subsection{Research Model or Design}

In order to examine the impact of the Covid-19 pandemic on the Casablanca financial centre, we will apply the event study methodology, which has been widely used to measure the effect of a non-economic event on the value (or return on equity) of a company. The event-study methodology is based on an overriding assumption of "market efficiency," which implies that stock prices incorporate all relevant information available to market participants (McWilliams \& Siegel, 1997). In fact, according to this methodology, when a market is efficient, any particular event will be reflected in the change in stock prices as well as in stock returns. However, it makes a second assumption, which assumes that the event under study is unexpected, i.e. that market participants do not have prior information about the event. However, when information is leaked to the market before an official announcement, the use of the event study methodology will be tricky, as it is difficult to determine when market participants became aware of the new information. For example, the methodology assumes the non-existence of confounding effects, i.e., abnormal returns are the result of the event being studied and not of another.

In order to assess the impact of the event on the stock markets, the methodology requires first estimating the abnormal return, which is the difference between the observed return and the expected return. If the announcement of an event is good news, we expect the abnormal returns to be positive, indicating that the market believes that the event will increase the value of the company. On the contrary, a negative abnormal return signals bad news and the market thinks the event will decrease the value of the company. Second, it is imperative to calculate the average abnormal return and the cumulative average abnormal return for the sampled companies in order to test its statistical significance. Indeed, if the cumulative average return is statistically different from zero, we can affirm that the event has a significant influence on stock prices.

\subsection{Data and Description}

This study focuses on the evaluation of the impact of the Covid-19 pandemic on the Moroccan stock market using an event study methodology. However, the event study methodology is based on the identification of two periods: the estimation period and the event period. In fact, it is common for the estimation window to be generally between 100 and 300 days (Peterson, 1989). For our study, we chose an estimation period of 200 trading days from April 30, 2019 to February 21, 2020. However, typical event window durations range from 21 to 212 days (Peterson, 1989). For our study, we chose the date of declaration of the state of health emergency by the Moroccan government as the event date, which is practically March 16, 2020 (trading day). Referring to related research (Buigut \& Kapar, 2019; Liu et al., 2020) we defined the event window as 50 trading days (see Figure 1). We used Microsoft Excel as the analysis tool for the study data that were extracted via the Casablanca Stock Exchange website. Concerning the sample, our study covered all companies listed on MASI except those that were suspended throughout the study period, namely: SAMIR, 2L ADH Jo1JAN2020 And DIAC SALAF. 


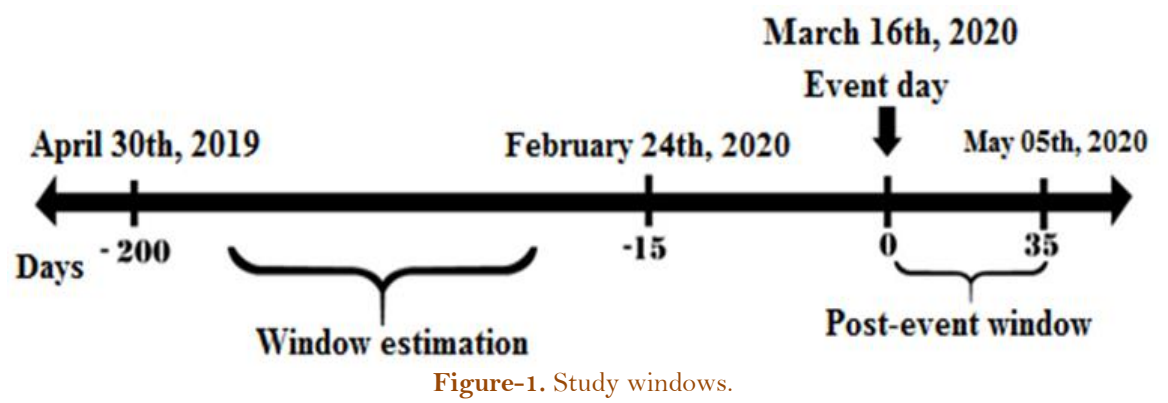

After defining the estimation and event periods, we then calculate the abnormal returns for the various companies listed on MASI. In fact, in order to measure the abnormal returns of companies, we need to estimate the expected returns for each of them. First, using the so-called market model (MM), we regressed the stock returns of MASI-listed companies against the return of the market index to control for overall market effects. The regression is presented as follows:

$$
R_{i, t}=\alpha_{i}+\beta_{i} R m_{t}+\varepsilon_{i, t}
$$

Where:

$$
R_{i, t}=\ln \left(P_{i, t} / P_{i t-1}\right)
$$

Where, $\mathrm{P}_{\mathrm{i}, \mathrm{t}}$ is the closing price of share $\mathrm{i}$ on day $\mathrm{t}$; $\mathrm{Rm}_{\mathrm{t}}$ represents the market return on day $\mathrm{t}$ which is the average of the returns of all companies included in the global index composed of all equity-type securities which is the Moroccan All Shares Index (MASI) for our study; $\varepsilon_{i, t}$ is the random error term for share i on day $t$, and $\alpha$ and $\beta$ are the regression parameters to be estimated which were applied in the following formulas to calculate the expected abnormal return:

$$
\begin{aligned}
& E\left(R_{i, t}\right)=\alpha_{i}+\beta_{i} R m_{t} \\
& A R_{i, t}=R_{i, t}+E\left(R_{i, t}\right)
\end{aligned}
$$

$E\left(R_{i, t}\right), R_{i, t}$ and $A R_{i, t}$ are respectively the expected return, the actual return and the abnormal return of share $\mathrm{i}$ on day $\mathrm{t}$. The average abnormal return of the shares in the sample on day $t$ is calculated as follows AAR:

$$
A A R=\frac{1}{N} \sum_{i=1}^{N} A R_{i, t}
$$

Where, $\mathrm{N}$ is the number of firms $(0,1,2, \ldots, 70,71,72)$. Abnormal and average abnormal performance can be cumulated over time. The Cumulative Abnormal Return (CAR) of share i over a period of time from $t_{0}$ to $t_{1}$ and the Cumulative Average Abnormal Return (CAAR) are calculated based on the following equations:

$$
\begin{aligned}
& C A R\left(t_{0}, t_{1}\right)=\sum_{t=t_{0}}^{t_{1}} A R_{i, t} \\
& C A A R\left(t_{0}, t_{1}\right)=\sum_{t=t_{0}}^{t_{1}} C A R
\end{aligned}
$$

Finally, to determine the significance of AAR, we used Student's parametric test:

$$
t=\frac{A A R}{\sigma(A A R)}
$$

\section{Results and Discussion}

We will first present the descriptive statistics, and then we will analyze the effect of the coronavirus on the Moroccan financial market.

\subsection{Descriptive Statistics}

Based on our analysis, we found a volatility of the average abnormal returns of companies listed on the Casablanca Stock Exchange ${ }^{3}$ between February 24, 2020 and May 5, 2020 (see Figure 2). Indeed, the stock market performed poorly before the event date. We can therefore expect that the state of health emergency will worsen the situation and that the market will continue a downward trend. Similarly, we note that the preevent period has seen average abnormal returns that vary in the range of $[-2 \% ; 1.5 \%]$. On March 09, 2020, the

${ }^{3}$ Previous studies carried out on the Moroccan financial market have shown that returns on financial assets do not follow the normal distribution (see (Agouram \& Lakhnati, 2015, 2016; Agouram \& Lakhnati, 2015)). 
stock market reacted negatively to the first years of infection by recording a rate of $-2.13 \%$. Then, on the following trading day, the market recovered and reacted positively to the situation by climbing to an average abnormal rate of return of $1.31 \%$. However, a few days before the event date, the market started to follow a downward trend, recording on March 12, 2020, a -1.99\% drop in yields, which proves that investors reacted as soon as the first cases of infection appeared on Moroccan territory.

Similarly, the date of the declaration of the state of health emergency by the Moroccan government on March 16, 2020, experienced an important reaction of the Moroccan stock market, reaching an average abnormal rate of return of $-2.54 \%$ which is the highest rate of the study, which shows the response of the Moroccan financial market to the Covid-19 pandemic at the time of the outbreak of the state of emergency. The Casablanca Stock Exchange continued its response in the post-event period but at a slower pace compared to the date of the event, with a variation range of $[-1 \%, 1 \%]$.

As noted above, the methodology for studying events assumes that abnormal returns are the result of the event under study, ruling out any confounding effects (McWilliams \& Siegel, 1997). As a result, the results of our study show a fluctuation in average abnormal returns throughout the study period, which proves, beforehand, that the Moroccan financial market reacted following the spread of the Covid-19 epidemic.

In order to assess in a profound way the effect of the pandemic on the Moroccan financial market, we will try in the following lines to calculate the cumulative abnormal returns for each event window, as well as the statistical test to verify their significance.

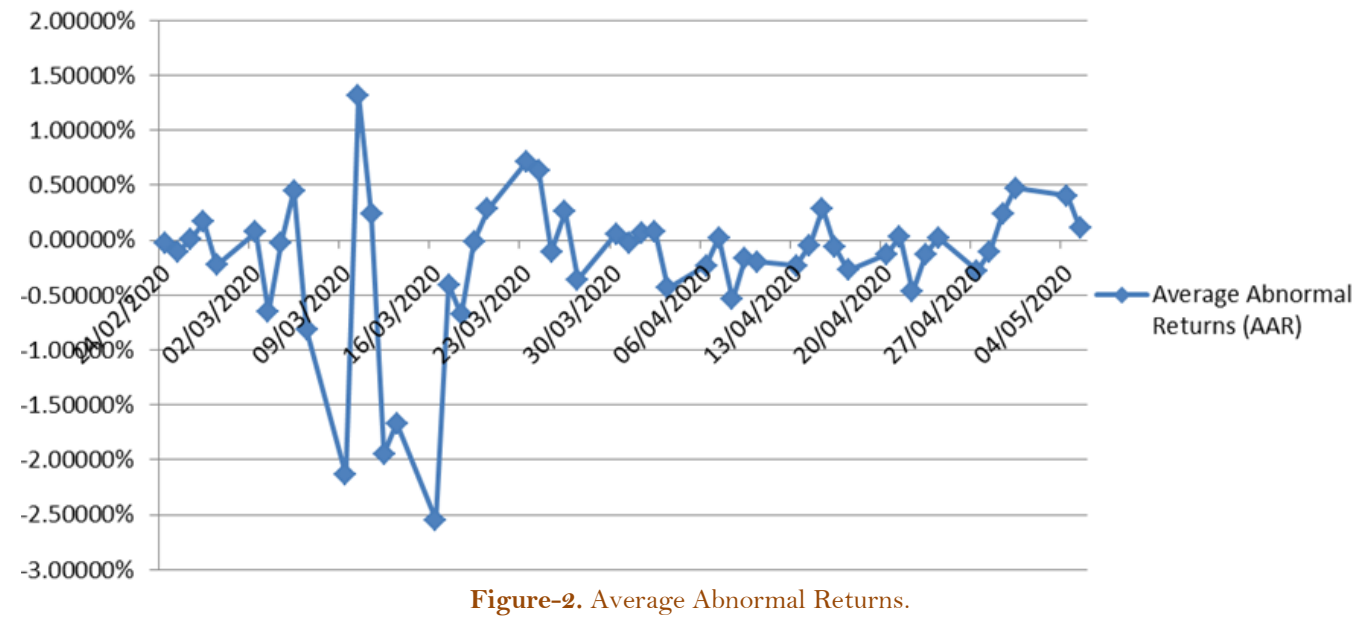

\subsection{Regression Results and Discussion}

Table 1 shows the cumulative average abnormal returns calculated using the market model and the statistical test $\mathrm{T}$ for the different event windows. The results show that the state of health emergency worsened the situation because on the day of the event the Moroccan financial market reacted quickly, recording a significant abnormal return of $-2.54 \%$. This indicates that the stock market suffered a serious negative impact when the news of the state of health emergency was broadcast by the Moroccan media. Cumulating the average abnormal returns over the three days surrounding the event, we see a significant increase in the average abnormal returns of $5 \%$, which shows that the event had a serious impact on the very short term. Similarly, the market shows a significant negative response for the window [-5;5], which proves that the pandemic impacted investor behavior.

When we aggregate the average abnormal returns over 5 days, 10 days and 35 days following the event date, we obtained, respectively, rates of $-2.65 \%,-2.17 \%$ and $-3.76 \%$, which were significantly lower than the initial abnormal returns, suggesting some market recovery. In fact, the Moroccan financial market was affected more in the very short term than in the long term, in other words, the Moroccan stock market suffered losses on the days surrounding the event date, while the market is beginning to recover, posting abnormal returns lower than those previously posted. Consequently, our results are in line with those of Ashraf (2020) who confirmed in his study that the Moroccan stock market reacts in the shortest term.

In this context, the good suggestion to give to investors is to proceed to sector diversifications, by taking positions on sectors that turn out not to be influenced by the pandemic, and geographic diversifications, by investing in markets where cases and deaths of Covid-19 are rare. They should even invest in sectors heavily affected by the pandemic will be a good option, as stocks purchased at this time may provide gains over the long term. 
Table-1. Cumulative average abnormal returns (CAAR).

\begin{tabular}{c|c|c}
\hline Window & CAR & t-test* \\
\hline$[\mathrm{O}]$ & $-2.5476 \%$ & -8.4895 \\
\hline$[-3 ; 3]$ & $-7.0241 \%$ & -8.8469 \\
\hline$[-5 ; 5]$ & $-6.8482 \%$ & -6.8807 \\
\hline$[0 ; 5]$ & $-2.6553 \%$ & -3.6124 \\
\hline$[0 ; 10]$ & $-2.1767 \%$ & -2.1870 \\
\hline$[0 ; 35]$ & $-3.7602 \%$ & -2.0884 \\
\hline Note: *Significant at the $5 \%$ level. & &
\end{tabular}

\section{Summary and Conclusions}

Indeed, the Coronavirus has evolved rapidly worldwide, leading to a paralysis of global economic systems. In this study we examined the effect of the Covid-19 pandemic on the Moroccan stock exchange during the period from 24th February 2020 to 5th May 2020 using the event study methodology. The latter is mainly based on the calculation of the cumulative average abnormal returns of the different securities composing the study sample. As a result, we calculated the daily abnormal returns of 72 companies listed on the Casablanca Stock Exchange and we cumulated them in order to verify their significance.

We find that the Casablanca Stock Exchange recorded statistically significant average abnormal returns. The results reveal that the Covid-19 pandemic had a negative influence on the Moroccan stock market, as the analyses showed significant average abnormal returns on the day the state of health emergency was declared in Morocco. Likewise for the windows of events, the Casablanca financial market posted negative abnormal returns. Thus, market reactions are more important on the shorter event windows than on the longer ones, which affirm that the pandemic had a rapid and immediate impact on the Moroccan market. Therefore, the results confirm the hypothesis of the $\mathrm{H} 1$ study by proving that the Moroccan financial market reacted strongly to the spread of the Covid-19 pandemic on the national territory with significant negative returns.

However, like any research work, our study has a number of limitations that we can exploit in future research, notably by using non-parametric tests to enrich the model's significance tests. Also, it will be imperative to broaden the scope of the study by integrating other emerging financial markets, notably Tunisia and Algeria, in order to verify the effect of the inter-country pandemic. Thus, it will be useful to assess the consequences of the pandemic on each sector of activity in order to analyse in depth its impact on the Moroccan market.

\section{References}

Agouram, J., \& Lakhnati, G. (2015). Mean-Gini portfolio selection: Forecasting VaR using GARCH models in Moroccan financial market. Journal of Economics and International Finance, 7(3), 51-58. Available at: https://doi.org/10.5897/jeif2014.0630.

Agouram, J., \& Lakhnati, G. (2016). Mean-Gini and mean-extended gini portfolio selection: An empirical analysis. Risk Governance \& Control: Financial Markets and Institutions, 6(3-1), 59-66. Available at: https://doi.org/10.22495/rcgv6i3c1art7.

Agouram, J., \& Lakhnati, G. (2015). A comparative study of mean-variance and mean Gini portfolio selection using VaR and CVaR. Journal of Financial Risk Management, 4(02), 72-81. Available at: https://doi.org/10.4236/jfrm.2015.42007.

Al-Awadhi, A. M., Al-Saifi, K., Al-Awadhi, A., \& Alhamadi, S. (2020). Death and contagious infectious diseases: Impact of the COVID-19 virus on stock market returns. Journal of Behavioral and Experimental Finance, $27,100326$. Available at: https://doi.org/10.1016/j.jbef.2020.100326.

Ali, M., Alam, N., \& Rizvi, S. A. R. (2020). Coronavirus (COVID-19)-An epidemic or pandemic for financial markets. Journal of Behavioral and Experimental Finance, 27, 100341. Available at: https://doi.org/10.1016/j.jbef.2020.100341.

Almarayeh, T. (2020). COVID-19 and stock markets response in developing countries. The case of MENA countries (June 16, 2020). Available at: SSRN: https://ssrn.com/abstract=3628395 or http://dx.doi.org/10.2139/ssrn.3628395.

Ashraf, B. N. (2020). Stock markets' reaction to COVID-19: Cases or fatalities? Research in International Business and Finance, 101249. Available at: https://doi.org/10.1016/j.ribaf.2020.101249.

Bora, D., \& Basistha, D. (2020). The outbreak of COVID-19 pandemic and its impact on stock market volatility: Evidence from a worst-affected economy.

Buigut, S., \& Kapar, B. (2019). Effect of Qatar diplomatic and economic isolation on GCC stock markets: An event study approach. Finance Research Letters, 101352. Available at: https://doi.org/10.1016/j.frl.2019.101352.

Chen, M.-H., Jang, S. S., \& Kim, W. G. (2007). The impact of the SARS outbreak on Taiwanese hotel stock performance: an event-study approach. International Journal of Hospitality Management, 26(1), 200-212. Available at: https://doi.org/10.1016/j.ijhm.2005.11.004.

Chesney, M., Reshetar, G., \& Karaman, M. (2011). The impact of terrorism on financial markets: An empirical study. Journal of Banking \& Finance, 35(2), 253-267. Available at: https://doi.org/10.1016/j.jbankfin.2010.07.026.

Choudhry, T. (2005). September 11 and time-varying beta of United States companies. Applied Financial Economics, 15(17), 1227-1242. Available at: https://doi.org/10.1080/09603100500358742. 
Corbet, S., Gurdgiev, C., \& Meegan, A. (2018). Long-term stock market volatility and the influence of terrorist attacks in Europe. The Quarterly Review of Economics and Finance, 68, 118-131. Available at: https://doi.org/10.1016/j.qref.2017.11.012.

Fama, E. F. (1970). Efficient capital markets: A review of theory and empirical work. The Journal of Finance, 25(2), $383-417$. Available at: https://doi.org/10.2307/2325487.

Fama, E. F., Fisher, L., Jensen, M. C., \& Roll, R. (1969). The adjustment of stock prices to new information. International Economic Review, 1O(1), 1-21. Available at: https://doi.org/10.2307/2525569.

Hirshleifer, D., \& Shumway, T. (2003). Good day sunshine: Stock returns and the weather. The Journal of Finance, 58(3), 1009-1032. Available at: https://doi.org/10.1111/1540-6261.00556.

Kaplanski, G., \& Levy, H. (2010). Sentiment and stock prices: The case of aviation disasters. Journal of Financial Economics, 95(2), 174-201. Available at: https://doi.org/10.1016/j.jfineco.2009.10.002.

Karolyi, G. A. (2006). The consequences of terrorism for financial markets: what do we know? Ohio State University, Working paper. Available at: https://doi.org/10.2139/ssrn.904398 or https://ssrn.com/abstract=904398.

Lepori, G. M. (2016). Air pollution and stock returns: Evidence from a natural experiment. Journal of Empirical Finance, 35 , 25-42. Available at: https://doi.org/10.1016/j.jempfin.2015.10.008.

Liu, H., Manzoor, A., Wang, C., Zhang, L., \& Manzoor, Z. (2020). The COVID-19 outbreak and affected countries stock markets response. International Journal of Environmental Research and Public Health, 17(8), 2800. Available at: https://doi.org/10.3390/ijerph17082800.

McWilliams, A., \& Siegel, D. (1997). Event studies in management research: Theoretical and empirical issues. Academy of Management Journal, 4O(3), 626-657. Available at: https://doi.org/10.5465/257056.

Nippani, S., \& Washer, K. M. (2004). SARS: a non-event for affected countries' stock markets? Applied Financial Economics, 14(15), 1105-1110. Available at: https://doi.org/10.1080/0960310042000310579.

Peterson, P. P. (1989). Event studies: A review of issues and methodology. Quarterly Journal of Finance and Accounting, 28(3), 36-66.

Sansa, N. A. (2020). The impact of the COVID-19 on the financial markets: Evidence from China and USA. Electronic Research Journal of Social Sciences and Humanities, 2(2). Available at: SSRN: https://ssrn.com/abstract=3567901 or http://dx.doi.org/10.2139/ssrn.3567901.

Scholes, M. S. (1972). The market for securities: Substitution versus price pressure and the effects of information on share prices. The Journal of Business, 45(2), 179-2 11. Available at: https://doi.org/10.1086/295444.

Şenol, Z. (2020). Coronavirus (COVID-19) and stock markets: The effects of the pandemic on the global economy. Eurasian Journal of Researches in Social and Economics (EJRSE), 7(4), 1-16.

Wang, W., \& Enilov, M. (2020). The global impact of COVID-19 on financial markets. Retrieved from: https://ssrn.com/abstract=3588021.

Worthington, A. C. (2008). The impact of natural events and disasters on the Australian stock market: A GARCH-M analysis of storms, floods, cyclones, earthquakes and bushfires. Global Business and Economics Review, 10(1), 1-10. 